\title{
THE EFFECTS OF FASTING AND FEEDING ON THE PROTEIN SYNTHESIS RATE AND POLYRIBOSOMAL PROFILE OF FROG PEPSINOGENIC CELLS
}

\author{
W. J. van VENROOIJ,* C. POORT and J. J. GEUZE \\ Laboratory of Histology and Cell Biology and the Centre for Electronmicroscopy, \\ Medical Faculty, State University of Utrecht, Utrecht, The Netherlands
}

\section{SUMMARY}

I. The rate of $\left[{ }^{14} \mathrm{C}\right]$ leucine incorporation into the protein of frog pepsinogenic cells was measured in both fasted and fed animals. The incorporation rate increases after feeding, becoming maximal after $2 \mathrm{~h}$.

2. In the oesophagi of fasted frogs, only monoribosomes and dimers are present. The absence of polyribosomes is not due to autolysis in the homogenate. After feeding, heavy polyribosomal aggregates appear.

3. It is concluded that feeding stimulates protein synthesis in frog pepsinogenic cells.

\section{INTRODUCTION}

It has formerly been shown that the rate of incorporation of labelled amino acids into mammalian pancreatic proteins was not influenced by feeding after a fasting period (Hokin, I956; Kramer \& Poort, I968; Poort \& Kramer, r969). However, with the pancreas of the frog we obtained different results. In winter, when the animal is normally hibernating, and also in summer, the rate of amino acid incorporation into pancreatic proteins is temporarily increased after feeding (Poort \& Geuze, I969; van Venrooij \& Poort, I97I). In order to make sure that an increase or decrease in the rate of amino acid incorporation is accompanied by an increase or decrease, respectively, in the rate of protein synthesis, we examined polyribosomal profiles.

From finding that the appearance of polyribosomal-bound monoribosomes coincides with an increase in amino acid incorporation rate, we concluded that the observed changes in incorporation rate induced by fasting and feeding reflect actual changes in protein synthesis (van Venrooij \& Poort, I97I). The incorporation rate does not appear to vary as a result of changes in an amino acid pool available for protein synthesis.

We were interested in whether the results obtained with the pancreas are equally valid for the other protein-secreting cells of the frog involved in digestion, such as the pepsinogen-secreting chief cells.

The present study shows by the same criteria that the rate of protein synthesis in

* Present address: Department of Biochemistry, University of Nijmegen, Nijmegen, The Netheriands. 
the pepsinogenic cells also increases after feeding. Whereas the rate of synthesis in the pancreas became maximal about $4 \mathrm{~h}$ after feeding, the pepsinogenic cells responded nure ranidly and were optimally active $2-3 \mathrm{~h}$ after the meal.

\section{WATIRIALS 1ND METHODS}

STiumens of Rana esculenta, caught and used in late spring and summer, were obtained fram $\mathbf{P}$. "an Leyen, Hensbroek, Holland, and kept in the laboratory in running water at about $15 \mathrm{C}$.

The animals were fasted for at least 3 days to ensure that their stomachs were entirely empty. I. the feeding experiments each frog was force fed with about $150 \mathrm{mg}$ of meat. The animals were decapitated and the caudal part of the oesophagus was removed immediately. The oesophagus was sliced longitudinally into 2 equal parts of about $10 \times 4 \mathrm{~mm}$ each. One part was used for determining the rate of $\left[{ }^{14} \mathrm{C}\right]$ leucine incorporation in vitro, and the other for preparing the polyribosomal profile.

\section{Rate of incorporation}

Oesophagus slices I mm thick were incubated in a solution containing $2 \mathrm{ml}$ of KrebsHenseleit bicarbonate buffer ( $\mathrm{pH} 7 \cdot 6)$, glucose ( $7 \mathrm{mM}),\left[{ }^{14} \mathrm{C}\right]$ leucine $\left(\mathrm{r} \mu \mathrm{Ci} / \mathrm{ml}\right.$, s.a. $3^{\mathrm{I}} \mathbf{2} \mathrm{mCi} /$ mmol), and the other unlabelled amino acids ( $\left(\mathrm{IO}^{-4} \mathrm{M}\right)$.

Incubation was carried out under an atmosphere of $\mathrm{O}_{2}-\mathrm{CO}_{2}(95: 5, \mathrm{v} / \mathrm{v})$ at $20{ }^{\circ} \mathrm{C}$ for $10 \mathrm{~min}$. The $\left[{ }^{14} \mathrm{C}\right]$ leucine incorporation was terminated by the addition of an ice-cold medium containing a large excess of unlabelled leucine. After 2 washings the slices were homogenized in $4.5 \mathrm{ml}$ of the same fluid, with a Potter homogenizer. The homogenate was filtered and the filtrate then divided into 4 portions of I ml each. Next, an equal volume of $20 \%$ trichloroacetic acid (TCA) containing an excess of leucine was added. The precipitate was washed twice with $5 \%$ TCA plus leucine, and twice with $96 \%$ ethanol.

Two pellets of precipitate were used for a duplicate DNA determination (Burton, 1956). The other 2 were dissolved in $0.5 \mathrm{ml}$ of Soluene TM-roo (Packard Instruments) and transferred to a scintillation vial together with $10 \mathrm{ml}$ of a toluene-based scintillation mixture.

\section{Isolation of polyribosomes}

The oesophagus was homogenized with a Potter homogenizer having a loose-fitting plunger, in ${ }^{\circ} .3 \mathrm{ml}$ of ice-cold Tris- $\mathrm{Mg}^{2+} \mathrm{KCl}$ buffer $(0.05 \mathrm{M}$ Tris- $\mathrm{HCl}, \mathrm{pH} 7.4$, $0.01 \mathrm{M}$ magnesium acetate and $0.025 \mathrm{M} \mathrm{KCl}$ ).

Cycloheximide (o. I mg per $\mathrm{ml}$ ) was added to the homogenate to prevent the formation of run-off ribosomes.

Debris, nuclei and some mitochondria were removed by a brief centrifugation $(5 \mathrm{~min}$ at $3000 \mathrm{~g}$ ) and then $0 \cdot \mathrm{r}$ volume of a $10 \%$ sodium deoxycholate solution was added to the supernatant. The resulting suspension was layered on to a $10-40 \%$ linear sucrose gradient in Tris$\mathrm{Mg}^{2+}-\mathrm{KCl}$ buffer. A $0 \cdot 2-\mathrm{ml}$ intermediate layer of $5 \%$ sucrose in Tris- $\mathrm{Mg}^{2+}-\mathrm{KCl}$ buffer was used to prevent proteins from entering the 10-40\% gradients.

The tubes were spun at $48000 \mathrm{rev} / \mathrm{min}$ in a Spinco SW $50^{\circ} \mathrm{I}$ rotor for $30 \mathrm{~min}$ and the contents analysed at $254 \mathrm{~nm}$ with a continuous-flow monitoring system.

\section{RESULTS}

\section{Morphology of the incorporating cells}

Earlier studies (Geuze, I97I $a, b$ ) have shown that in the frog the pepsinogenic cells are concentrated in glands of the caudal part of the oesophagus, in which they are not coexistent with parietal cells as they are in mammals. In the glands, only a 
Table $1 .\left[{ }^{14} \mathrm{C}\right]$ Leucine incorporation in vitro in frog oesophagus expressed in dpm per $\mu g$ of $D N A$

\begin{tabular}{lcc}
\hline & $\begin{array}{c}\text { Treatment of } \\
\text { animal }\end{array}$ & \multicolumn{1}{c}{ Incorporation } \\
\hline Fasted & $(7)^{*}$ & $\mathrm{I6}\left(\mathrm{I}^{\circ} 5\right) \dagger$ \\
Hours after feeding & I (5) & $75($ II $)$ \\
& $2(5)$ & IO5 (I3) \\
& $3(5)$ & $76(26)$ \\
& $4(6)$ & $26(8)$ \\
& * Number of animals. $†$ s.E.M. values. \\
\hline
\end{tabular}

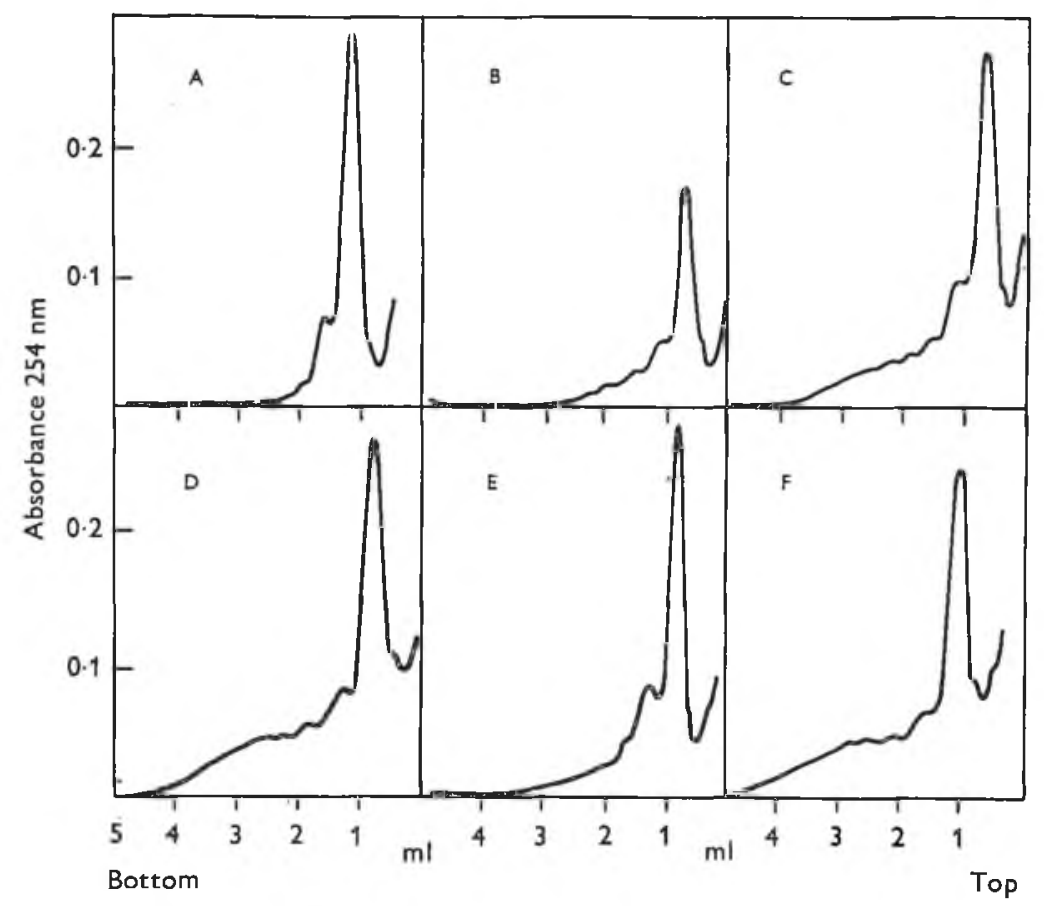

Fig. I. The effect of feeding on the polyribosomal profile of the frog oesophagic cells. Polyribosomes were isolated from fasted animals (A), from animals I, 2, 3 and $4 \mathrm{~h}$ after feeding (B to $\mathrm{B}$, respectively) and from a mixture ( $\mathrm{F}$ ) of oesophageal homogenate from a fasted animal and from one $3 \mathrm{~h}$ after feeding.

few mucous neck cells are present. The surface epithelium is composed of ciliated cells, with a few goblet cells.

The mucous neck cells, ciliated cells and goblet cells (which are altogether few in number compared to the pepsinogenic cells), and the tunica propria cells are largely inactive in the in vitro (Fig. 2A) and in vivo (M. F. Kramer, unpublished observations) incorporation of radioactive leucine. Fig. $2 \mathrm{~B}$ shows that only the pepsinogenic cells incorporate $\left[{ }^{14} \mathrm{C}\right]$ leucine actively. The incorporation data can therefore be attributed to the activity of the pepsinogenic cells. 
Incorporation of $\left[{ }^{14} \mathrm{C}\right]$ leucine in vitro

The $\left[{ }^{14} \mathrm{C}\right]$ leucine incorporation (in $\mathrm{dpm}$ per $\mu \mathrm{g}$ of $\mathrm{DNA}$ ) increased after feeding. The incorporation rate was highest about $2 \mathrm{~h}$ after the meal ('Table I) and thenceforth gradually decreased.

\section{Polyribosomal profile}

After prolonged fasting no polyribosomes were present (Fig. I). However, after feeding, at the time when the rate of $\left[{ }^{14} \mathrm{C}\right]$ leucine incorporation rises, polyribosomes appeared and gradually increased in size and number. When the incorporation rate was low again ( $4 \mathrm{~h}$ after food intake) most of the polyribosomes had disappeared.

The absence of polyribosomes in fasted oesophagus could conceivably result from autolysis following homogenization. To examine this possibility we mixed the oesophageal homogenate of a fasted frog with that of a 3-h fed frog. In this mixed homogenate there were presumably polyribosomes from the fed animal, not yet degraded (Fig. I F).

It can be concluded that the absence of polyribosomes in fasted frog oesophagus is not caused by autolysis during the isolation procedure.

\section{DISCUSSION}

In our experiments with frog oesophagus we have found that after a meal sufficiently large to trigger protein synthesis, the $\left[{ }^{14} \mathrm{C}\right]$ leucine incorporation rate in pepsinogenic cells increases. Such an increase does not necessarily reflect an increased protein synthesis rate, because it might otherwise be accounted for by a contingent change in the specific activity of the precursor pool. However, the simultaneous appearance of polyribosomes strongly suggests that the increased incorporation rate is largely the result of an increased rate of protein synthesis.

Similarly, the disappearance of the polyribosomes about $4 \mathrm{~h}$ after the feeding is consistent with the assumption that the observed decreased amino acid incorporation rate indeed reflects a lessening of protein synthesis.

It is perhaps significant that at the time when synthesis begins to decrease again in the pepsinogenic cells, the synthesis in the pancreas becomes maximal (van Venrooij \& Poort, I97I). Assuming that synthesis can be accelerated with similar post-activation time lags in both types of cells, we suggest that the cells are necessarily activated in the order consistent with the time course of digestion.

The stretching of mucosa by food content has been suggested as a stimulus for cell secretion, since pepsin output depends on the strength and duration of mechanical stimuli (Smit, 1964). At present, there is no conclusive evidence indicating a relationship between such secretion stimulation and accelerated protein synthesis.

The technical assistance of Miss G. W. Best and Mrs A. C. Dutmer-Korteweg is gratefully acknowledged. This research was partly supported by the Netherlands Foundation for Chemical Research (SON), with financial aid also from the Netherlands Organization for the Advancement of Pure Research (Z.W.O.). 


\section{REFERENCES}

Burton, K. (1956). A study of the conditions and mechanism of the diphenylamine reaction for the colorimetric estimation of deoxyribonucleic acid. Biochem. $7.62,315-322$.

GeuZE, J. J. ( (971 $a$ ). Light and electron microscope observations on the gastric mucosa of the frog (Rana esculenta). I. Normal structure. Z. Zellforsch. mikrosk. Anat. II7, 87-102.

GeuzE, J. J. (197 $b$ ). Light and electron microscope observations on the gastric mucosa of the frog (Rana esculenta). II. Structural alterations during hibernation. Z. Zellforsch. mikrosk. Anat. I17, 103-117.

HokiN, M. R. (1956). The formation of amylase by mouse pancreas in vitro. F. biol. Chem. 219, $77-83$.

Kramer, M. F. \& Poort, C. (1968). Protein synthesis in the pancreas of the rat after stimulation of secretion. Z. Zellforsch. mikrosk. Anat. 86, 475-486.

PoorT, C. \& GEUZE, J. J. (1969). The effect of temperature elevation and feeding on the pancreas of Rana esculenta in late winter. A biochemical and ultrastructural study. Z. Zellforsch. mikrosk. Anat. 98, I-8.

Poort, C. \& Kramer, M. F. (1969). Effect of feeding on the protein synthesis in mammalian pancreas. Gastroenterology $57,689-696$.

SMIT, H. (1964). The regulation of pepsin secretion in the edible frog Rana esculenta (L). Comp. Biochem. Physiol. 13, 129-141.

VAN VenRooIJ, W. J. \& PoORT, C. (I971). Rate of protein synthesis and polyribosome formation in the frog pancreas after fasting and feeding. Biochim. biophys. Acta 247, 468-470.

(Received I4 August I972) 
Fig. 2. Light-microscopic radioautographs of incubated slices of frog oesophagus. Slices were incubated as described in Methods for $20 \mathrm{~min}$ in a medium containing Io $\mu \mathrm{Ci}\left[{ }^{3} \mathrm{H}\right]$ leucine per $\mathrm{ml}$, then fixed in phosphate-buffered formaldehyde ( $\left.\mathrm{pH} 7 \cdot 4\right)$; 5- $\mu \mathrm{m}$ sections were covered with Kodak stripping film AR Io, exposed for 30 days at room temperature and developed in Drg-b.

$A$, the epithelial lining of the oesophagus lumen is composed of goblet cells $(g c)$ and ciliated cells $(c c)$. Only slight incorporation has taken place in these cells. $\times$ I200.

$B$, section through oesophagus glands with pepsinogenic cells. Note the relative high degree of labelling in these cells. $\times 1200$. 


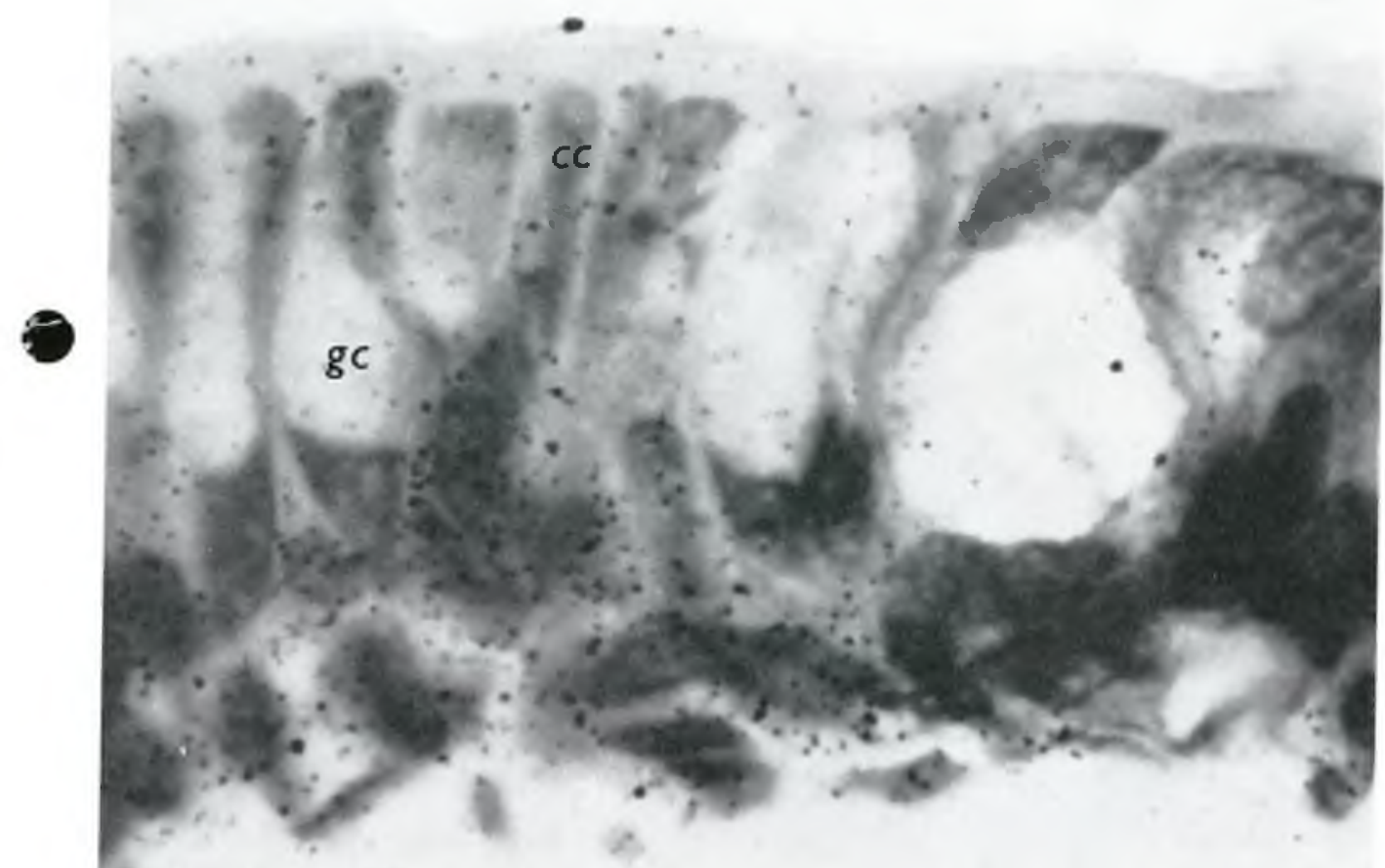

\section{A}

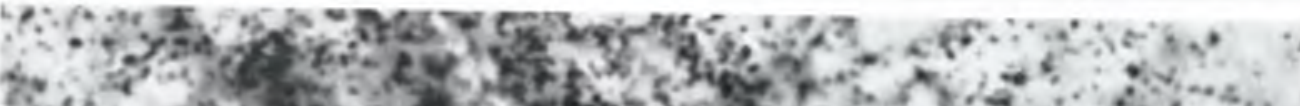

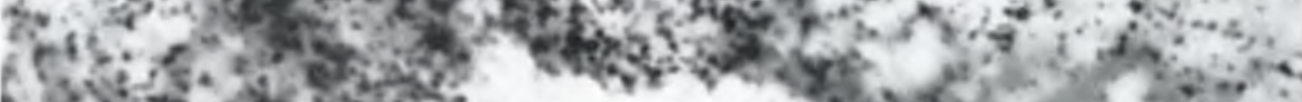

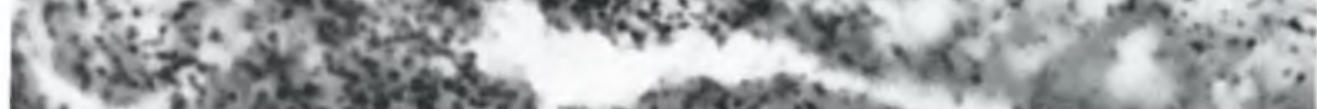

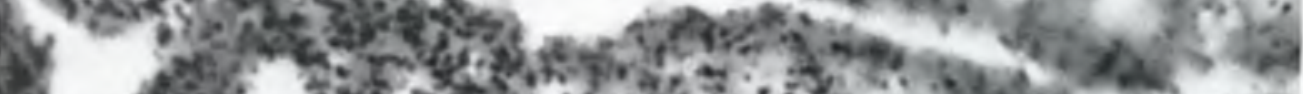

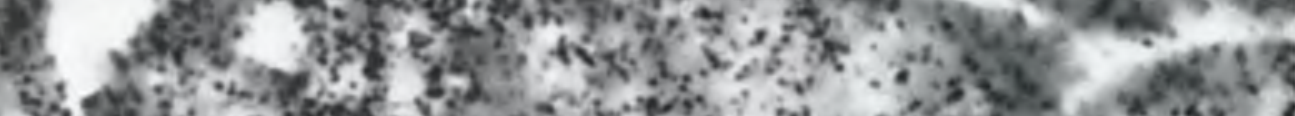

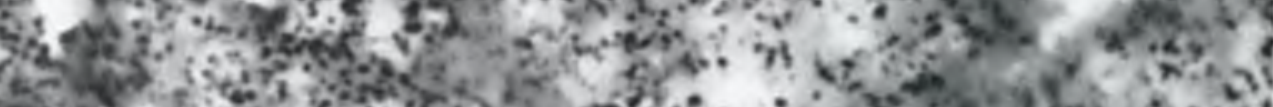

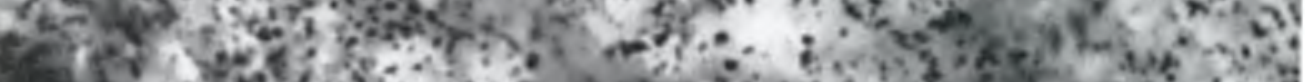

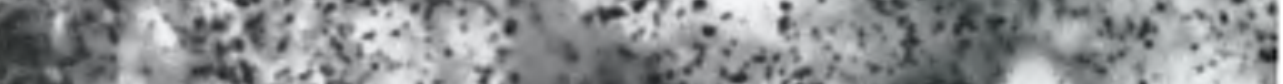

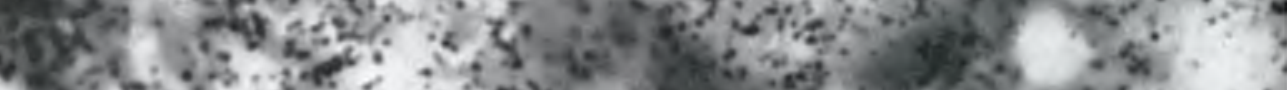



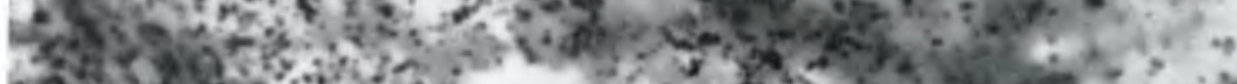

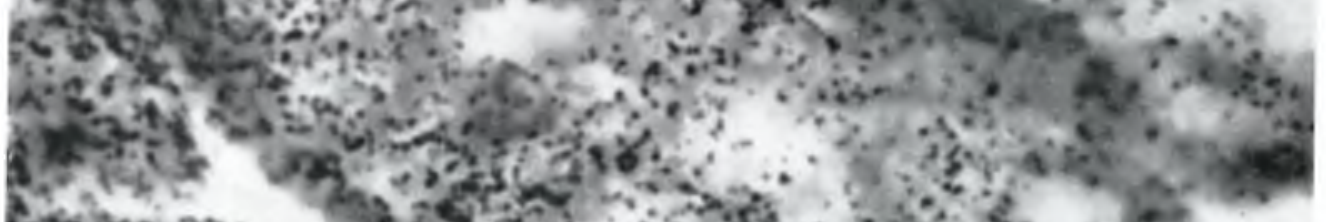

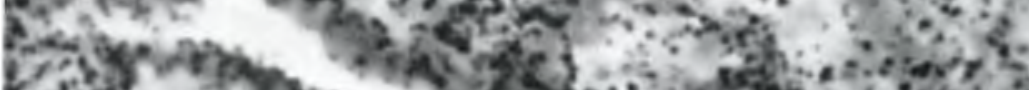
E.

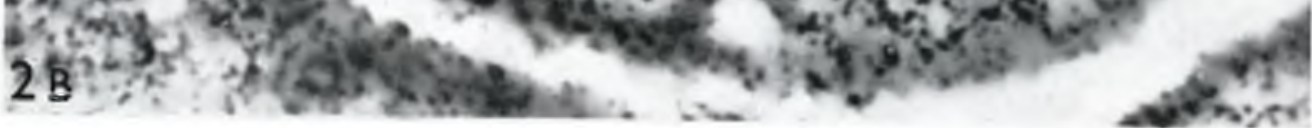

